\title{
Removal of phenol from aqueous solutions by adsorption onto Mn-Ce-K solids
}

\author{
Oriana D'Alessandro • Horacio Thomas • \\ Jorge E. Sambeth
}

Received: 10 April 2014/Accepted: 29 June 2014

(C) Akadémiai Kiadó, Budapest, Hungary 2014

\begin{abstract}
Mn-Ce solids were used for the adsorption of phenol from aqueous solution at 25 and $50{ }^{\circ} \mathrm{C}$. The samples were prepared with a $\mathrm{Mn}-\mathrm{Ce}$ molar ratio between 0 and $100 \%$ by the alkaline co-precipitation method $(\mathrm{KOH})$. Structural studies showed the formation of cryptomelane, $\mathrm{Mn}_{2} \mathrm{O}_{3}, \mathrm{Mn}_{5} \mathrm{O}_{8}, \mathrm{Mn}_{3} \mathrm{O}_{4}$ and $\mathrm{CeO}_{2}$. The formation of different phases is a function of the Ce concentration. The adsorption isotherms of phenol were determined and modelled with Langmuir and Freundlich equations. Sample 7/3 had a high adsorption capacity. Thermodynamic parameters, in flat and vertical position of phenol, were calculated. These parameters indicated that the adsorption of phenol onto Mn-Ce was spontaneous and exothermic. The DRIFTS study detected of both phenol and phenolate species adsorbed on the surface and the aromatic ring of phenol is parallel to the surface. The interaction between $\mathrm{Mn}$ and Ce enhanced the reducibility of the oxides and activated oxygen, which is favorable for the adsorption process.
\end{abstract}

Keywords Phenol adsorption · Alkaline precipitation $\cdot \mathrm{Mn}-\mathrm{Ce}-\mathrm{K}$. Thermodynamic parameters

\section{Introduction}

Phenolic compounds are used in different enterprises such as chemical, petroleum, paper, and petrochemical plants. Phenol and its derivates are considered as priority pollutants due to their toxicity at low concentrations. According to the World Health Organization, the permissible concentration of phenolic contents in potable water is $1 \mu \mathrm{g} \mathrm{L}^{-1}$.

O. D’Alessandro $\cdot$ H. Thomas · J. E. Sambeth $(\bowtie)$

Centro de Investigación y Desarrollo en Ciencias Aplicadas "Dr. Jorge J. Ronco", CINDECA FCE, UNLP, CCT CONICET LA PLATA - 47 N 257 (1900), La Plata, Argentina

e-mail: sambeth@quimica.unlp.edu.ar 
Several processes have been employed for the removal of phenolic compounds from aqueous solutions such as catalytic wet air oxidation, oxidation with ozone, electrochemical oxidation, photocatalytic degradation, adsorption and solvent extraction [1-6].

Activated carbon and clay minerals (bentonite, kaolinite, illite) are known processes have been widely used because they have a large surface area and high adsorption capacity. However, the adsorption of phenol is influenced by the properties of the solids (oxidation state, oxygen vacancies, hollow structure, etc.). For these reasons, new adsorbents such as $\mathrm{MnO}_{2}, \mathrm{TiO}_{2}$, and $\mathrm{Fe}_{2} \mathrm{O}_{3}$ have been reported. In recent years, many authors have studied the adsorption of organic compounds such as phenol, clarithromycin and catechol onto manganese oxides. Their results have shown that the oxidation states and the morphology are important factors in the adsorption process [7-9].

The aim of this work is to analyze phenol adsorption onto Mn-Ce solids. The isotherm studies were conducted to evaluate the adsorption capacity as a function of the physicochemical properties of the Mn-Ce samples.

\section{Experimental}

Synthesis: $\mathrm{K}(\mathrm{OH})$ was added to an aqueous solution of $\mathrm{Ce}\left(\mathrm{NO}_{3}\right)_{3} \cdot 6 \mathrm{H}_{2} \mathrm{O}$ (SigmaAldrich) and $\mathrm{Mn}\left(\mathrm{NO}_{3}\right)_{2} \cdot 4 \mathrm{H}_{2} \mathrm{O}$ (Anedra). The solids were prepared with molar ratios (Mn/Ce) 10/0 (pure manganese oxide), 7/3, 5/5, 3/7 and 0/10 (pure cerium oxide). All solids were dried at $100{ }^{\circ} \mathrm{C}$ to constant weight and calcined in air at $350{ }^{\circ} \mathrm{C}$ for $3 \mathrm{~h}$.

Characterization: powder X-ray diffraction (XRD) was performed on Philips PW 1390 using $\mathrm{CuK}_{\alpha}$ radiation. FTIR spectra were measured on Bruker Vertex 70 accumulating 32 scans at a resolution of $4 \mathrm{~cm}^{-1}$. X-ray photoelectron spectra (XPS) were obtained with a system of multi-technical equipment Phoibos 150 . The specific surface areas of the catalysts were estimated using $\mathrm{N}_{2}$ adsorption isotherms at $-196{ }^{\circ} \mathrm{C}$ by the BET method employing the Micromeritics ASAP 2020. Temperature-programmed reduction (TPR) measurements were carried out at atmospheric pressure in a fixed-bed reactor $\left(\mathrm{m}=50 \mathrm{mg}\right.$, hydrogen flux $=30 \mathrm{~mL} \mathrm{~min}{ }^{-1}, 6.5 \%$ $\mathrm{H}_{2} / \mathrm{Ar}$, heating rate $5{ }^{\circ} \mathrm{C} \mathrm{min}^{-1}$ ) using a Quantachrome Quantasorb Jr. instrument.

Adsorption study adsorption experiments were conducted by the batch technique. For each isotherm, $50 \mathrm{mg}$ of $\mathrm{Mn}-\mathrm{Ce}$ sample and $5 \mathrm{~g} \mathrm{~mL}^{-1}$ of phenol solution of given concentrations between 0.125 and $1 \mathrm{~g} \mathrm{~L}^{-1}$ were used. The system was placed into a cryostatic bath. The adsorption temperatures were 25 and $50{ }^{\circ} \mathrm{C}$. The suspensions were mixed in a rotary tumbler for $24 \mathrm{~h}(27.3 \mathrm{rpm})$. Samples were separated by filtration and phenol concentrations were analyzed by UV-VIS spectroscopy (Perkin-Elmer Lambda 35) at $\lambda_{\max }$ 270, 274, 280 and $290 \mathrm{~nm}$. In this work, Langmuir and Freundlich models were used to describe the relationship between the amount of phenol adsorbed and its equilibrium concentration in solution. 
The adsorption equilibrium constant at infinite dilution (Ko) was calculated as:

$$
K o=\frac{\gamma_{a d s} C_{a d s}}{\gamma_{e q} C_{e q}},
$$

here, $\gamma_{\mathrm{ads}}$ and $\gamma_{\mathrm{eq}}$ are the activity coefficients of adsorbed phenol and water, respectively; $\mathrm{C}_{\mathrm{ads}}$ is the concentration of the adsorbed species $\left(\mu \mathrm{g} \mathrm{mL}{ }^{-1}\right)$ and $\mathrm{C}_{\mathrm{eq}}$ is $\mu \mathrm{g}$ of phenol per millilitre of equilibrium solution.

The value of $\mathrm{C}_{\mathrm{ads}}$ was calculated as

$$
C_{a d s}=\frac{\left[\left(\frac{\rho_{\mathrm{H}_{2} \mathrm{O}}}{M_{\mathrm{H}_{2} \mathrm{O}}}\right) A_{\mathrm{H}_{2} \mathrm{O}}\right]}{\left[\left(\frac{S \times 10^{4}}{N A q e}\right)-\left(\frac{A_{\text {phenol }}}{M_{\text {phenol }} \times 10^{6}}\right)\right]},
$$

here $\rho_{\mathrm{H}_{2} \mathrm{O}}$ is the density of water $\left(\mathrm{g} \mathrm{mL}^{-1}\right), M_{\mathrm{H}_{2} \mathrm{O}}$ is the molecular weight of water $\left(\mathrm{g} \mathrm{mol}^{-1}\right), \mathrm{M}_{\mathrm{fenol}}$ is the molecular weight of phenol $\left(\mathrm{g} \mathrm{mol}^{-1}\right)$, NA is the Avogadro constant, qe is the amount of adsorbed phenol $\left(\mu \mathrm{g} \mathrm{g}^{-1}\right), \mathrm{S}$ is the surface area of $\mathrm{Mn}-$ Ce sample $\left(\mathrm{m}^{2} \mathrm{~g}^{-1}\right), A_{\mathrm{H}_{2} \mathrm{O}}$ is the area of water molecule $\left(9.9 \AA^{2}\right.$ molecule $\left.{ }^{-1}\right)$, $\mathrm{A}_{\text {phenol }}$ is the area of phenol (41.0 and $21.7 \AA^{2}$ molecule ${ }^{-1}$ in vertical and flat orientation onto Mn-Ce solid [10, 11].

The activity coefficients are a function of the ionic strength and the temperature. According to Linares et al. [12] $\gamma_{\mathrm{ads}}$ and $\gamma_{\mathrm{eq}}$ lead to one at infinite dilution, so Eq. 1 can be rewritten in the form:

$$
K o=\lim _{C_{a d s} \rightarrow 0}\left(\frac{C_{a d s}}{C_{e q}}\right)
$$

Ko was calculated assuming the adsorption of phenol can be vertical (v) or flat (f) and taking into account that the activity coefficients may change with the ionic strength [12].

The thermodynamic functions were calculated according to [13]:

$$
\begin{gathered}
\Delta G^{0}=-R T \ln K o \\
\ln K o\left(T_{2}\right)-\ln K o\left(T_{1}\right)=\frac{-\Delta H^{0}}{R}\left(\frac{1}{T_{2}}-\frac{1}{T_{1}}\right) \\
\Delta G^{0}=\Delta H^{0}-T \Delta S^{0}
\end{gathered}
$$

here, $\Delta \mathrm{G}^{0}=$ standard free energy; $\Delta \mathrm{H}^{0}=$ enthalpy, $\Delta \mathrm{S}^{0}=$ entropy, $\mathrm{R}=$ gas universal constant $\left(8.314 \mathrm{~J} \mathrm{~mol}^{-1} \mathrm{~K}^{-1}\right)$ and $\mathrm{T}=$ absolute temperature.

DRIFT spectroscopy the DRIFTS analysis was carried out in Bruker Vertex 70 equipment using a cell Spectra Tech 0030-011. After the reaction, the samples were dried in $\mathrm{N}_{2}$ atmosphere at room temperature for $24 \mathrm{~h}$. The DRIFT spectra were obtained in $\mathrm{N}_{2}$ atmosphere, with a spectral resolution of $4 \mathrm{~cm}^{-1}$ and accumulation of 500 scans at RT. 


\section{Results and discussion}

Fig. 1 shows the XRD patterns. The results of the XRD characterization indicate: (i) for $\mathrm{Mn}-\mathrm{Ce} 10 / 0$, the formation of $\mathrm{Mn}_{2} \mathrm{O}_{3}$ (JCPDS \# 06-0540), $\mathrm{MnO}_{2}$ (JCPDS \# 39-0375), $\mathrm{Mn}_{3} \mathrm{O}_{4}$ (JCPDS \# 18-0803), $\mathrm{Mn}_{5} \mathrm{O}_{8}$ (JCPDS \# 39-1218) and cryptomelane $\mathrm{K}_{\mathrm{x}}\left(\mathrm{Mn}^{4+}, \mathrm{Mn}^{3+}\right)_{6} \mathrm{O}_{12}$ (JCPDS \# 34-0168), (ii) for Mn-Ce 0/10, the presence of $\mathrm{CeO}_{2}$ phase with fluorite structure (JCPDS \# 43-1002), and (iii) for Mn-Ce 7/3, 5/5 and 3/7 solids, XRD measurements showed the structure of $\mathrm{CeO}_{2}$ and manganese oxides.

Fig. 2 illustrates the FTIR spectra of the samples. In the Mn/Ce 10/0 sample, three peaks were detected at $520 \mathrm{~cm}^{-1}, 617 \mathrm{~cm}^{-1}$ and $970 \mathrm{~cm}^{-1}$, which are assigned to the $\mathrm{O}-\mathrm{Mn}-\mathrm{O}$ and $\mathrm{Mn}-\mathrm{OH}$ stretching vibrations $[14,15]$. The first two peaks appeared in the $\mathrm{Mn} / \mathrm{Ce} 7 / 3,5 / 5$ and 3/7 solids. The FTIR spectrum of Mn/Ce $0 / 10$ presents two peaks. One of them at $850 \mathrm{~cm}^{-1}$ and the other at $1,061 \mathrm{~cm}^{-1}$, which may be attributed to $\mathrm{O}-\mathrm{Ce}-\mathrm{O}$ and $\mathrm{O}-\mathrm{Ce}-\mathrm{OH}$, respectively [16]. The band at $970 \mathrm{~cm}^{-1}$ was assigned to $\mathrm{Mn}^{3+}$ and it disappeared when Ce was incorporated.

The XPS spectra of Mn $2 p$ in the samples with Mn show a broad band at $640.7 \mathrm{eV}$, which could be associated with the oxidation states $\mathrm{Mn}^{2+}, \mathrm{Mn}^{3+}$ and $\mathrm{Mn}^{4+}$ [17]. Table 1 lists the binding energy (BE) of the bands Mn 2p3/2 and 2p1/2. As can be seen (Fig. 3), between the samples 10/0 and 5/5, there is a shift towards higher energies of $1.6 \mathrm{eV}$, which may indicate a strong interaction between $\mathrm{Mn}$ and Ce [18]. The Mn-Ce 3/7 solid shows a lower shift than the other solids. We suggest

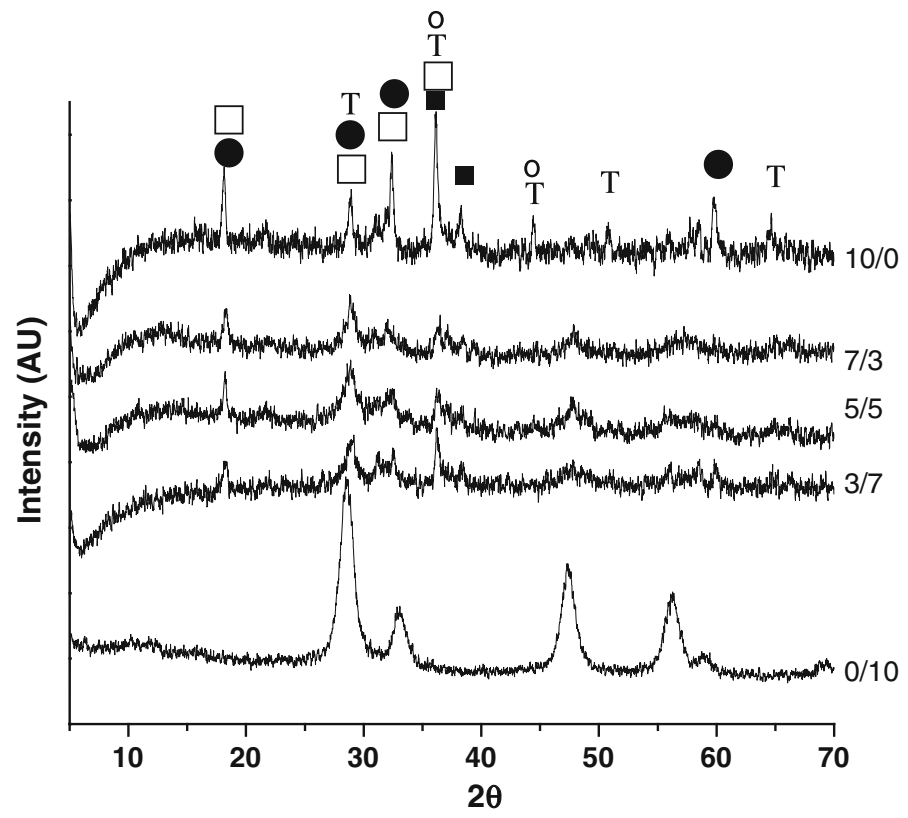

Fig. 1 XRD of the solids: (filled circle) $\mathrm{Mn}_{2} \mathrm{O}_{3}$, (filled square) $\mathrm{MnO}_{2}$, (unfilled circle) $\mathrm{Mn}_{3} \mathrm{O}_{4}$, (unfilled square) $\mathrm{Mn}_{5} \mathrm{O}_{8}$ and $(\mathrm{T})$ cryptomelane 


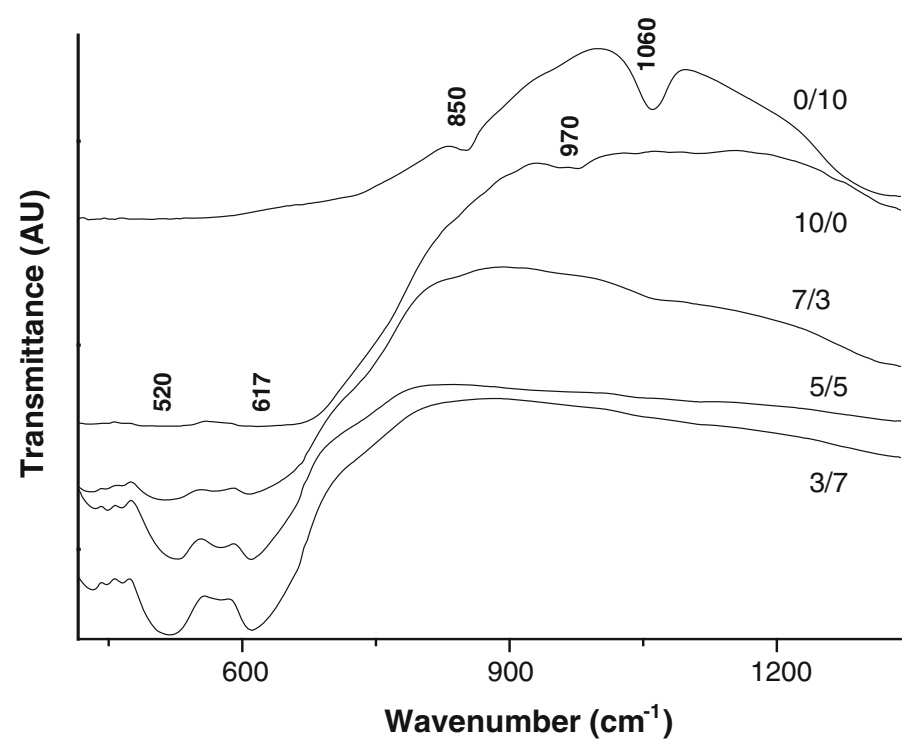

Fig. 2 IR spectra for Mn-Ce solids

Table 1 Binding energies (BE) of Mn 2p3/2, 2p1/2 and average oxidation state (AOS) of Mn

\begin{tabular}{|c|c|c|c|}
\hline Sample & $\mathrm{BE} \mathrm{Mn} 2 \mathrm{p}_{3 / 2}(\mathrm{eV})$ & $\mathrm{BE} \operatorname{Mn} 2 \mathrm{p}_{1 / 2}(\mathrm{eV})$ & AOS \\
\hline $\mathrm{Mn}-\mathrm{Ce}(\mathrm{K}) \quad 10 / 0$ & 641.9 & 653.5 & 3.64 \\
\hline $\mathrm{Mn}-\mathrm{Ce}(\mathrm{K}) 7 / 3$ & 642.5 & 654.0 & 3.49 \\
\hline $\mathrm{Mn}-\mathrm{Ce}(\mathrm{K}) 5 / 5$ & 643.5 & 655.1 & 3.57 \\
\hline $\mathrm{Mn}-\mathrm{Ce}(\mathrm{K})$ 3/7 & 642.4 & 654.1 & 3.20 \\
\hline
\end{tabular}

that this phenomenon should be associated with a decreased $\mathrm{Mn}-\mathrm{Ce}$ interaction, which could be due to low Mn concentration.

Table 1 also shows the average oxidation states (AOS) for each sample. The determination of the average oxidation state of manganese was calculated according to [19]. The results show the presence of $\mathrm{Mn}^{3+}-\mathrm{Mn}^{4+}$.

The $\mathrm{O} 1 \mathrm{~s}$ region shows two different oxygen species. The BE of 529-530 eV may be associated with lattice oxygen $\left(\mathrm{O}^{2-}\right)$, denoted as $\mathrm{O}_{\alpha}$, and the $\mathrm{BE}$ of 531-532 eV might be assigned to defect oxide or $\mathrm{OH}$, called $\mathrm{O}_{\beta}[19,20]$. Table 2 shows the BE of both types of oxygen and their percentages. All the samples showed an amount of $\mathrm{O}_{\alpha}$ higher than that of $\mathrm{O}_{\beta}$. However, both $7 / 3$ and 5/5 solids have the highest percentages of $\mathrm{O}_{\alpha}$.

With respect to $\mathrm{Ce}$, the study of the $\mathrm{Ce} 3 \mathrm{~d}$ region indicates the presence of three bands at 879-890, 895-913 and $918 \mathrm{eV}$. These bands may suggest the presence of $\mathrm{Ce}^{3+}$ and $\mathrm{Ce}^{4+}$ species [20]; in particular, the component around $918 \mathrm{eV}$ is assigned to the formation of $\mathrm{Ce}^{4+}[21]$. 


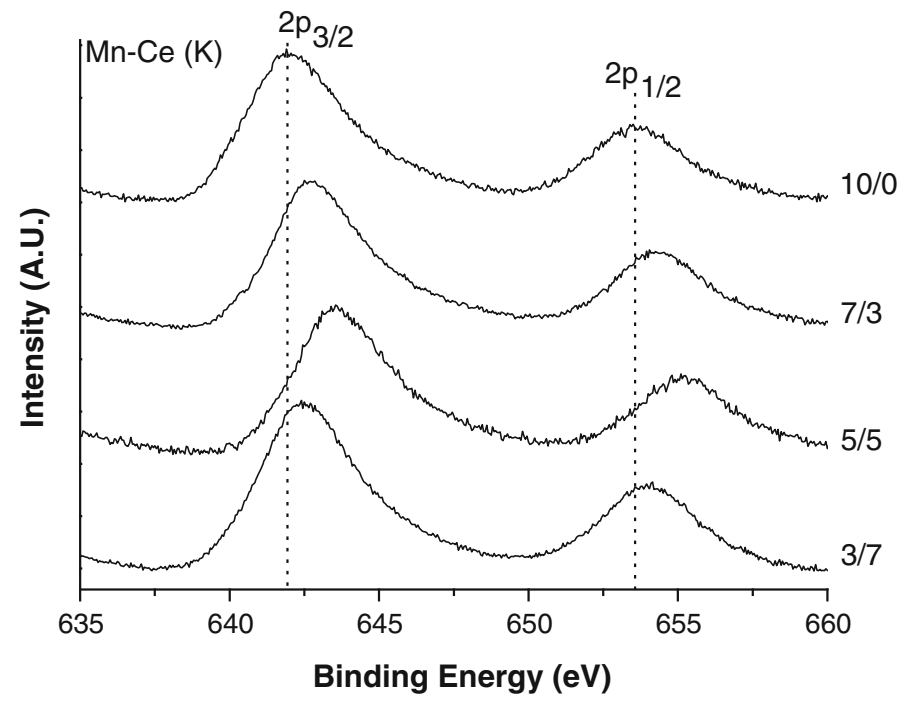

Fig. 3 Mn2p XPS spectra of the Mn/Ce samples

Table 2 Binding energies (BE) of both types of oxygen as well as their percentage in each sample

\begin{tabular}{lllll}
\hline Sample & $\mathrm{BE} \mathrm{O}_{\alpha}(\mathrm{eV})$ & $\mathrm{BE} \mathrm{O}_{\beta}(\mathrm{eV})$ & $\mathrm{O}_{\alpha}(\%)$ & $\mathrm{O}_{\beta}(\%)$ \\
\hline $\mathrm{Mn}-\mathrm{Ce}(\mathrm{K}) \mathrm{10/0}$ & 529.9 & 531.5 & 62.9 & 36.1 \\
$\mathrm{Mn}-\mathrm{Ce}(\mathrm{K}) \mathrm{7/3}$ & 529.9 & 531.9 & 72.0 & 28.0 \\
$\mathrm{Mn}-\mathrm{Ce}(\mathrm{K}) 5 / 5$ & 529.8 & 531.9 & 72.9 & 27.1 \\
$\mathrm{Mn}-\mathrm{Ce}(\mathrm{K}) 3 / 7$ & 530.0 & 531.7 & 58.1 & 41.9 \\
$\mathrm{Mn}-\mathrm{Ce}(\mathrm{K})$ 0/10 & 529.8 & 531.4 & 52.9 & 46.1 \\
\hline
\end{tabular}

Table 3 Pore volume, specific surface area and pore size of $\mathrm{Mn}-\mathrm{Ce}$ samples

\begin{tabular}{|c|c|c|c|c|}
\hline Sample & $\begin{array}{l}\text { Pore volume } \\
\left(\mathrm{cm}^{3} / \mathrm{g}\right)\end{array}$ & $\begin{array}{l}\text { Surface area. } \\
\left(\mathrm{m}^{2} / \mathrm{g}\right)\end{array}$ & $\begin{array}{l}\text { Ceria particle } \\
\text { size } d_{\mathrm{CeO} 2}(\mathrm{~nm})^{\mathrm{a}}\end{array}$ & $\begin{array}{l}\text { Pore } \\
\text { size }(\AA)\end{array}$ \\
\hline $\mathrm{Mn}-\mathrm{Ce}(\mathrm{K}) \quad 10 / 0$ & 0.187 & 25 & - & 277 \\
\hline $\mathrm{Mn}-\mathrm{Ce}(\mathrm{K}) 7 / 3$ & 0.325 & 56 & 5.2 & 221 \\
\hline $\mathrm{Mn}-\mathrm{Ce}(\mathrm{K}) 5 / 5$ & 0.324 & 88 & 5.1 & 145 \\
\hline $\mathrm{Mn}-\mathrm{Ce}(\mathrm{K}) 3 / 7$ & 0.276 & 55 & 5.7 & 183 \\
\hline $\mathrm{Mn}-\mathrm{Ce}(\mathrm{K}) 0 / 10$ & 0.149 & 123 & 4.6 & 52 \\
\hline
\end{tabular}

\footnotetext{
${ }^{a}$ From the Scherrer equation, applied to the (111) reflection of the cerianite
}

The surface areas, pore volumes, particle size and pore sizes are summarized in Table 3. The results demonstrated that with the increase in Mn content, the surface area decreased with respect to $\mathrm{Mn} / \mathrm{Ce} 0 / 10$. The values of average particle size of $\mathrm{CeO}_{2}\left[(111) ; 2 \theta=28.5^{\circ}\right]$, as calculated using the Scherrer equation. $\mathrm{Mn} / \mathrm{Ce} 0 / 10$ 
has a crystal size of $4.6 \mathrm{~nm}$ and $\mathrm{Mn} / \mathrm{Ce}$ composites have a particle size in the range of $5.3 \mathrm{~nm}$. This result is in accordance with the surface area measurements, which show that $\mathrm{Mn} / \mathrm{Ce} 0 / 10$ has a higher surface area than the other solids. The particle size did not affect the capacity of adsorption.

Fig. 4 shows the $\mathrm{H}_{2}$-TPR profiles of $\mathrm{Mn} / \mathrm{Ce}$ solids. For the $\mathrm{Mn} / \mathrm{Ce} 10 / 0$ sample two reduction peaks located at 341 and $465^{\circ} \mathrm{C}$, which correspond to the two-step reduction process $\mathrm{MnO}_{2}$ or $\mathrm{Mn}_{2} \mathrm{O}_{3}$ to $\mathrm{Mn}_{3} \mathrm{O}_{4}$ and that of $\mathrm{Mn}_{3} \mathrm{O}_{4}$ to $\mathrm{MnO}$, can clearly be observed. In addition, the $\mathrm{Mn} / \mathrm{Ce} 10 / 0$ sample has a broad peak at $255^{\circ} \mathrm{C}$. According to Kapteijn [22], this broad peak is associated with the presence of $\mathrm{MnO}_{2}$ wtih disordered structure. It can be seen that all $\mathrm{Mn} / \mathrm{Ce}(7 / 3,5 / 5$ and 3/7) solids show similar TPR profiles, although the two peaks shift towards lower temperatures. These phenomena indicate that the reduction of $\mathrm{MnO}_{\mathrm{x}}$ is favored by Ce addition $[23,24]$.

Fig. 5 shows the results of the adsorption study. As can be seen, the process is favorable at both temperatures. It is very interesting to observe that in pure $\mathrm{MnOx}$ and $\mathrm{CeO}_{2}$, phenol adsorption is negligible. The results show that sample $7 / 3$ has a high adsorption capacity. This observation is consistent with different results [25, 26], which have showed that the phenol adsorption is favored with a higher concentration of $\mathrm{Mn}^{4+}$.

Table 4 presents the adsorption constants for Langmuir and Freundlich models. An increase is observed when the temperature rises from 25 to $50{ }^{\circ} \mathrm{C}$. The results of adsorption experiments show that the adsorption capacity increases with the temperature. A similar behavior was observed by [27] when the adsorbent was graphene. In both models, the $\mathrm{r}^{2}$ values showed that both Langmuir and Freundlich isotherm models could describe the adsorption process. This may be due to both

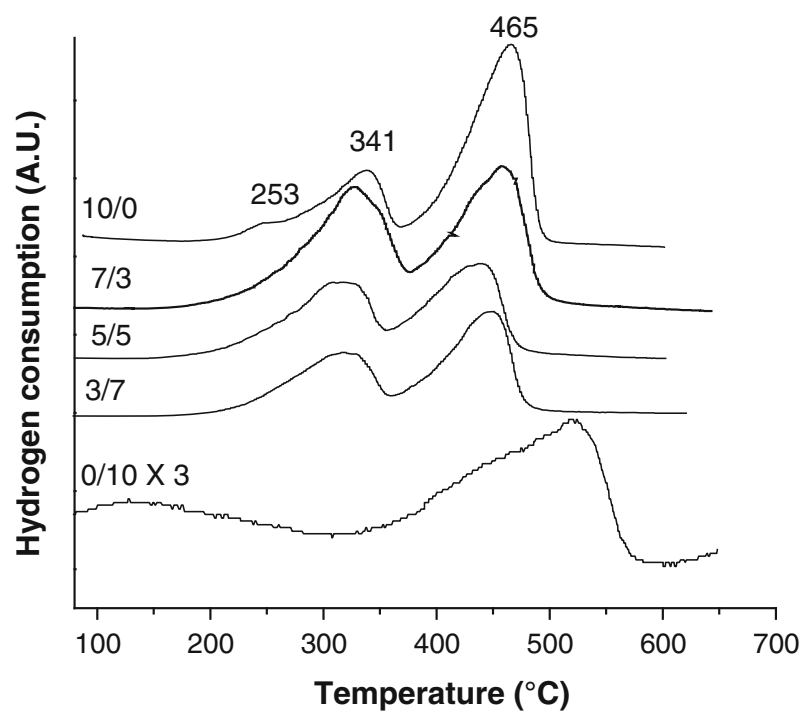

Fig. $4 \mathrm{H}_{2}$ TPR profiles of the Mn/Ce mixed oxides 


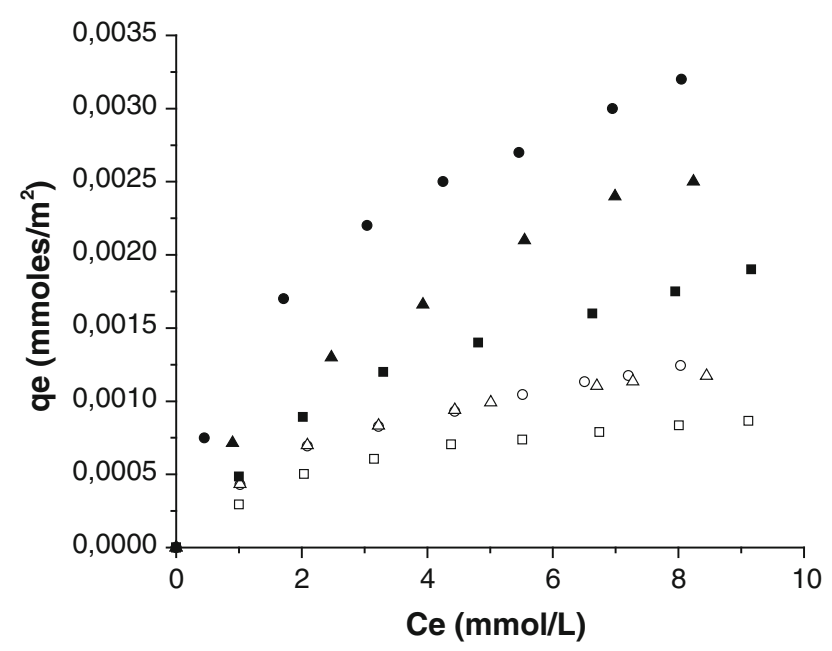

Fig. 5 Phenol adsorption isotherms at 25 and $50{ }^{\circ} \mathrm{C}$. Filled circle $\mathrm{Mn}-\mathrm{Ce} 7 / 3$, filled triangle $\mathrm{Mn}-\mathrm{Ce} 3 / 7$ and filled square $\mathrm{Mn}-\mathrm{Ce} 5 / 5$ at $50{ }^{\circ} \mathrm{C}$ unfilled circle $\mathrm{Mn}-\mathrm{Ce} 7 / 3$, unfilled triangle $\mathrm{Mn}-\mathrm{Ce} 3 / 7$ and unfilled square $\mathrm{Mn}-\mathrm{Ce} 5 / 5$ at $25^{\circ} \mathrm{C}$

Table 4 Adsorption constants for Ce-Mn series at 25 and $50{ }^{\circ} \mathrm{C} ; \mathrm{Ka}\left(\mathrm{L} \mathrm{mmol}^{-1}\right)$ adsorption equilibrium constant, $\mathrm{qm}\left(\mathrm{mmol} \mathrm{m}^{-2}\right)$ the amount of phenol adsorbed for a complete monolayer, $\mathrm{K}_{\mathrm{F}}$ Freundlich constant, $\mathrm{n}_{\mathrm{F}}$ empirical parameter

\begin{tabular}{lllllll}
\hline Sample & $\mathrm{Ka}$ & $\mathrm{qm}$ & $\mathrm{r}^{2}$ & $\mathrm{~K}_{\mathrm{F}}$ & $\mathrm{n}_{\mathrm{F}}$ & $\mathrm{r}^{2}$ \\
\hline $25{ }^{\circ} \mathrm{C}$ & & & & & & \\
$\mathrm{Mn}-\mathrm{Ce} 7 / 3$ & 0.176 & $2.12 \times 10^{-3}$ & 0.999 & $4.49 \times 10^{-4}$ & 2.0 & 0.995 \\
$\mathrm{Mn}-\mathrm{Ce} \mathrm{5/5}$ & 0.381 & $1.12 \times 10^{-3}$ & 0.999 & $3.31 \times 10^{-4}$ & 2.1 & 0.988 \\
$\mathrm{Mn}-\mathrm{Ce} \mathrm{3/7}$ & 0.381 & $1.53 \times 10^{-3}$ & 0.999 & $4.68 \times 10^{-4}$ & 2.2 & 0.989 \\
$50^{\circ} \mathrm{C}$ & & & & & & \\
$\mathrm{Mn}-\mathrm{Ce} \mathrm{7/3}$ & 0.562 & $3.55 \times 10^{-3}$ & 0.999 & $1.38 \times 10^{-3}$ & 2.5 & 0.999 \\
$\mathrm{Mn}-\mathrm{Ce} \mathrm{5/5}$ & 0.213 & $2.81 \times 10^{-3}$ & 0.999 & $6.61 \times 10^{-4}$ & 2.1 & 0.997 \\
$\mathrm{Mn}-\mathrm{Ce} \mathrm{3/7}$ & 0.220 & $3.85 \times 10^{-3}$ & 0.998 & $7.76 \times 10^{-4}$ & 1.7 & 0.999 \\
\hline
\end{tabular}

homogeneous and heterogeneous distribution of active sites on the surface of the $\mathrm{Mn} / \mathrm{Ce}$ solids.

Table 5 lists the thermodynamic parameters. The adsorption equilibrium constant (Ko) was calculated assuming the adsorption of phenol can be vertical (v) or flat (f) and taking into account that the activity coefficients may change with the ionic strength [14]. The results show that the $\mathrm{Ko}_{25}$ (f) constant is higher than $\mathrm{Ko}_{25}$ (v), but both $\mathrm{Ko}_{50}$ (v) and $\mathrm{Ko}_{50}$ (f) constants are similar.

The values of $\Delta \mathrm{H}^{0}, \Delta \mathrm{G}^{0}$ and $\Delta \mathrm{S}^{0}$ were calculated from Eqs. 4, 5 and 6.

The negative values of $\Delta \mathrm{G}^{0}$ indicate that the process is spontaneous at both temperatures. In addition, the decrease in the magnitude of $\Delta \mathrm{G}^{0}\left(25^{\circ} \mathrm{C}\right)$ showed the adsorption is more favorable over the $\mathrm{Mn}-\mathrm{Ce} 7 / 3$ sample than over the other solids. 
Table 5 Thermodynamic parameters of $\mathrm{Mn}-\mathrm{Ce}$ at 25 and $50{ }^{\circ} \mathrm{C}$

\begin{tabular}{|c|c|c|c|c|c|c|c|c|}
\hline \multirow[t]{2}{*}{ Sample } & \multirow[t]{2}{*}{$\mathrm{Ko}_{25}(\mathrm{f})$} & \multirow[t]{2}{*}{$\mathrm{Ko}_{25}(\mathrm{v})$} & \multicolumn{2}{|c|}{$\Delta \mathrm{G}^{0}\left(\mathrm{KJ} \mathrm{mol}^{-1}\right)$} & \multicolumn{2}{|c|}{$\Delta \mathrm{H}^{0}\left(\mathrm{KJ} \mathrm{mol}^{-1}\right)$} & \multicolumn{2}{|c|}{$\Delta \mathrm{S}^{0}\left(\mathrm{KJ}^{\circ} \mathrm{K}^{-1} \mathrm{~mol}^{-1}\right)$} \\
\hline & & & $\mathrm{f}$ & $\mathrm{v}$ & $\mathrm{f}$ & $\mathrm{v}$ & $\mathrm{f}$ & $\mathrm{v}$ \\
\hline $\mathrm{Mn}-\mathrm{Ce}(\mathrm{K}) 7 / 3$ & 7.62 & 5.83 & -5.03 & -4.37 & 4.28 & 13.3 & 0.031 & 0.060 \\
\hline $\mathrm{Mn}-\mathrm{Ce}(\mathrm{K}) 5 / 5$ & 7.49 & 4.05 & -4.99 & -3.46 & 0.592 & 20.6 & 0.019 & 0.081 \\
\hline $\mathrm{Mn}-\mathrm{Ce}(\mathrm{K}) 3 / 7$ & 5.91 & 4.32 & -4.40 & -3.62 & 9.41 & 19.8 & 0.046 & 0.079 \\
\hline \multirow[t]{2}{*}{ Sample } & \multirow[t]{2}{*}{$\mathrm{Ko}_{50}(\mathrm{f})$} & \multirow[t]{2}{*}{$\mathrm{Ko}_{50}(\mathrm{v})$} & \multicolumn{2}{|c|}{$\Delta \mathrm{G}^{0}\left(\mathrm{KJ} \mathrm{mol}^{-1}\right)$} & \multicolumn{2}{|c|}{$\Delta \mathrm{H}^{0}\left(\mathrm{KJ} \mathrm{mol}^{-1}\right)$} & \multicolumn{2}{|c|}{$\Delta \mathrm{S}^{0}\left(\mathrm{KJ}^{\circ} \mathrm{K}^{-1} \mathrm{~mol}^{-1}\right)$} \\
\hline & & & $\mathrm{f}$ & $\mathrm{v}$ & $\mathrm{f}$ & $\mathrm{v}$ & $\mathrm{f}$ & $\mathrm{v}$ \\
\hline $\mathrm{Mn}-\mathrm{Ce}(\mathrm{K}) 7 / 3$ & 8.71 & 8.83 & -5.81 & -5.85 & 4.28 & 13.3 & 0.031 & 0.060 \\
\hline $\mathrm{Mn}-\mathrm{Ce}(\mathrm{K}) 5 / 5$ & 7.63 & 7.71 & -5.45 & -5.48 & 0.592 & 20.6 & 0.019 & 0.081 \\
\hline $\mathrm{Mn}-\mathrm{Ce}(\mathrm{K})$ 3/7 & 7.93 & 8.01 & -5.56 & -5.58 & 9.41 & 19.8 & 0.046 & 0.079 \\
\hline
\end{tabular}

The positive value of the enthalpy change indicates that the interaction between adsorbed phenol and the surface is an endothermic process. Finally, the positive $\Delta S^{0}$ value suggests an increased randomness in the adsorbent-solution interface during this process [27]. The positive values may be due to some structural changes both in the adsorbate and the adsorbent during the adsorption process, i.e. the displacement of the adsorbed water molecules by the adsorbate.

DRIFT spectra of phenol adsorbed on three solids $\left(7 / 3,5 / 5\right.$ and 3/7) at $25{ }^{\circ} \mathrm{C}$ were recorded and are shown in Fig. 6. Bands around 1,640, 1,510, 1,490 and $1,330 \mathrm{~cm}^{-1}$ are observed on three samples. The bands are assigned to: (i) olefinic $\mathrm{C}=\mathrm{C}$ stretching $\left(1,636 \mathrm{~cm}^{-1}\right)$, (ii) $\mathrm{C}=\mathrm{C}$ and $\mathrm{C}=\mathrm{C}-\mathrm{H}$ stretching in aromatic compounds $\left(1,512 \mathrm{~cm}^{-1}\right)$, (iii) $\mathrm{C}-\mathrm{H}$ symmetric deformation in $\mathrm{OCH}_{2}$ groups $\left(1,490 \mathrm{~cm}^{-1}\right)$ and (iv) $\mathrm{OH}$ species of phenol $\left(1,332 \mathrm{~cm}^{-1}\right)$.

A band at $1,205 \mathrm{~cm}^{-1}$ appears with increasing Ce content (Mn-Ce 5/5 and 3/7). According to Mathew et al. [28] this band can be attributed to $>\mathrm{C}-\mathrm{O}$-groups. The presence $>\mathrm{C}-\mathrm{O}$-vibration between 1,230 and $1,210 \mathrm{~cm}^{-1}$ is indicative deprotonated phenol. The deprotonation of phenol is due to the interaction of phenolic group and an acid-base site.

On the other hand, Mathew et al. [28] have demonstrated that the formation of bands between 2,100 and $1,700 \mathrm{~cm}^{-1}$, when interaction phenol-surface occurs, are a signal that the adsorption of phenol is perpendicular to surface. As it can be seen (Fig. 6), these bands are not detected in this work. Finally, the results of the thermodynamic parameters and DRIFT spectroscopy suggest that phenol is adsorbed in flat position.

The results showed that at high Mn loadings, the phenol adsorption is favoured. The presence of $\mathrm{CeO}_{2}$ could influence in the adsorption mechanism (formation of phenolate). On the basis of the results reported in this paper, it can be concluded that: (i) the adsorption of phenol on the Mn-Ce solid is independent of the structural properties, but the process is a function of the $\mathrm{Mn}-\mathrm{Ce}$ interaction, (ii) IR analysis detected of both phenol and phenolate species adsorbed on all solids and $\mathrm{Mn}-\mathrm{Ce} 5 / 5$ and $3 / 7$, and (iii) phenol is chemisorbed in flat position. 


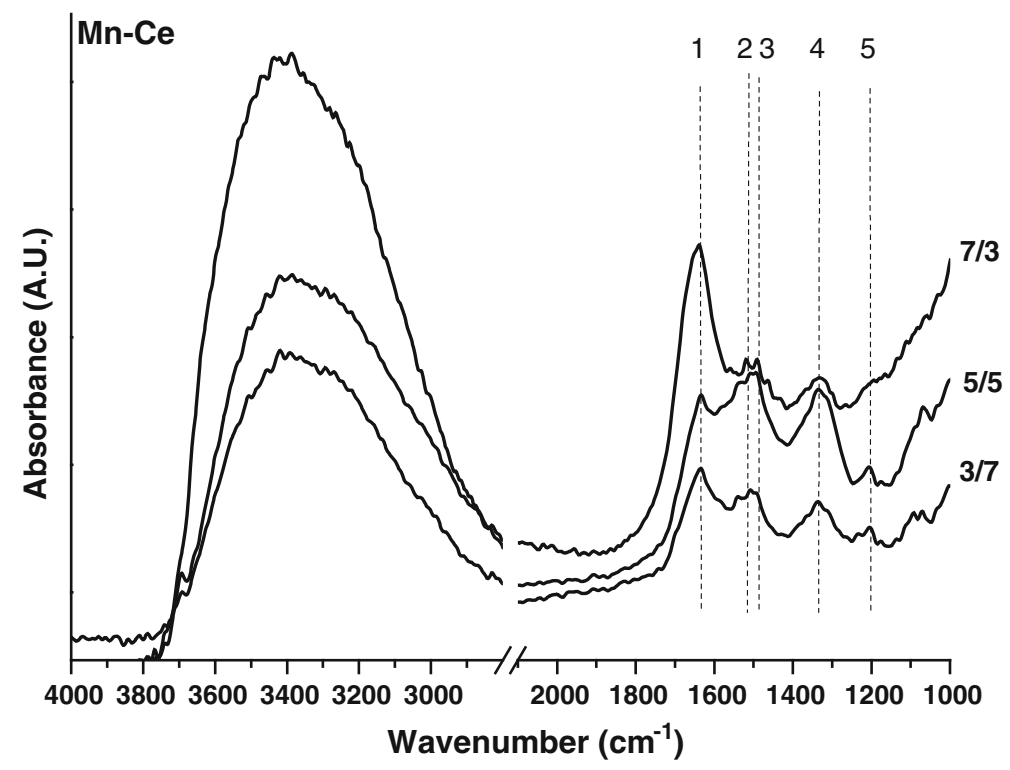

Fig. 6 DRIFT spectra of phenol adsorbed on Mn/Ce mixed oxides. References: $11,636 \mathrm{~cm}^{-1}$, $21,511 \mathrm{~cm}^{-1}, 31,490 \mathrm{~cm}^{-1}, 41,332 \mathrm{~cm}^{-1}, 51,205 \mathrm{~cm}^{-1}$

\section{Conclusions}

Phenol adsorption was studied over manganese/cerium composites, which were prepared by alkaline co-precipitation with $\mathrm{KOH}$. The adsorption process was analyzed at 25 and $50{ }^{\circ} \mathrm{C}$. The results showed: (i) the formation of different phases of $\mathrm{MnOx}$ and $\mathrm{CeO}_{2}$ as a function of the molar ratio, (ii) the presence of redox couple $\mathrm{Mn}^{3+} / \mathrm{Mn}^{4+}$, and (iii) a stronger interaction between $\mathrm{Mn}$ and Ce. The adsorption capacity of $\mathrm{Mn}-\mathrm{Ce} 7 / 3$ is higher than that of $\mathrm{Mn}-\mathrm{Ce} 5 / 5$ and 3/7 solids. In addition, the adsorptions of phenol onto the $\mathrm{Mn}-\mathrm{Ce} 10 / 0$ and $0 / 10$ samples are negligible. This result suggested that the capacity is a function of the presence of both metals. The process is spontaneous and endothermic, and the positive $\Delta S^{0}$ values could suggest that the organization of the adsorbate at the solid/solution interface becomes more random. The phenol is adsorbed in parallel form to the surface through the interaction between $\mathrm{OH}$ of phenol and acid-base pair site.

Acknowledgments The authors are grateful to Graciela Valle for your technical assistance. In addition, the authors thank the financial support by CONICET and UNLP.

\section{References}

1. Hamoudi S, Larachi F, Sayari A (1998) Wet oxidation of phenolic solutions over heterogeneous catalysts: degradation profile and catalyst behavior. J Catal 177:247-258

2. Qin G, Yao Y, Wei W, Zhang T (2013) Preparation of hydrophobic granular silica aerogels and adsorption of phenol from water. Appl Surf Sci 280:806-811 
3. Imamura S (1999) Catalytic and noncatalytic wet oxidation. Ind Eng Chem Res 38:1743-1753

4. Wu J, Rudy K, Spark J (2000) Oxidation of aqueous phenol by ozone and peroxidise. Adv Environ Res 4:339-346

5. Namane A, Ali O, Cabana H, Hellal A (2012) Evaluation of biological treatments for the adsorption of phenol from polluted waters. Ads Sci Tech 30:521-532

6. Qiang Z, Chang JH, Huang CP (2003) Electrochemical generation of hydrogen peroxide from dissolved oxygen in acidic solutions. Water Res 37(1):85-94

7. Hidalgo MC, Murcia JJ, Navío JA, Colón G (2011) Photodeposition of gold on titanium dioxide for photocatalytic phenol oxidation. Appl Catal A 397:112-120

8. Yang L, Chen Z, Zhang D, Liu Y, Han Y, Shen J (2011) Adsorption of dimethylamine from aqueous solution by manganese dioxide. Water Sci Tech 63:45-50

9. Hu B, Chen C, Frueh SJ, Jin L, Joesten R, Sui S, Suib L (2010) Removal of aqueous phenol by adsorption and oxidation with doped hydrophobic cryptomelane-type manganese oxide (K-OMS-2) nanofibers. J Phys Chem C 114:9835-9844

10. Fu Y, Hansen RS, Bartell FE (1948) Thermodynamics of adsorption from solutions. I. The molality and activity co-efficient of adsorbed layers. J Phys Chem 52:374-386

11. Bertoncini C, Odetti H (2000) Computer simulation of phenol physisorption on graphite. Langmuir 16:7457-7463

12. Linares J, Huertas F, Caballero E, Jimenez de Cisneros C (1998) Physicochemical relationships during a $\mathrm{KCl}$-bentonite hydrothermal reaction. Clay Miner 33:475-482

13. Niwas R, Gupta U, Khan AA, Varshney KG (2000) The adsorption of phosphamidon on the surface of styrene supported zirconium (IV) tungstophosphate: a thermodynamic study. Colloids Surf A 164:115-119

14. Julien CM, Massot M (2003) Spectroscopic studies of the structural transitions in positive electrodes for lithium batteries. J Power Sources 119-121:743-748

15. Boyero Macstre J, Fernandez Lopez E, Gallardo-Amores JM, Ruano Casero R, Sanchez Escribano V, Perez Bernal E (2001) Influence of tile synthesis parameters on the structural and textural properties of precipitated manganese oxides. Int J Inorg Mater 7:889-899

16. Gadsden JA (1975) Infrared spectra of minerals and related inorganic compounds. Butterworths, Sussex

17. Tseng TK, Chu H, Hsu HH (2003) Characterization of $\gamma$-alumina-supported manganese oxide as an incineration catalyst for trichloroethylene. Environ Sci Technol 37:171-176

18. Ferrandon M, Carno J, Jaras S, Bjornbom E (1999) Total oxidation catalysts based on manganese or copper oxides and platinum or palladium I: characterisation. Appl Catal A 180:141-151

19. Oku M (1995) X-ray photoelectron spectra of $\mathrm{KMnO}_{4}$ and $\mathrm{K}_{2} \mathrm{MnO}_{4}$ fractured in situ. J Electron Spectrosc Relat Phenom 74:135-148

20. Larachi F, Pierre J, Adnot A, Bernis A (2002) Ce 3d XPS study of composite $\mathrm{Ce}_{\mathrm{x}} \mathrm{Mn}_{1-\mathrm{x}} \mathrm{O}_{2-\mathrm{y}}$ wet oxidation catalysts. Appl Surf Sci 195:236-250

21. Beche E, Charvin P, Perarnau D, Abanades S, Flamant G (2008) Ce 3d XPS investigation of cerium oxides and mixed cerium oxide $\left(\mathrm{Ce}_{\mathrm{x}} \mathrm{Ti}_{\mathrm{y}} \mathrm{O}_{\mathrm{z}}\right)$. Surf Interface Anal 40:264-267

22. Kapteijn F, Singoredjo L, Andreini A, Moulijn JA (1994) Activity and selectivity of pure manganese oxides in the selective catalytic reduction of nitric oxide with ammonia. Appl Catal B 3:173-189

23. Stobbe ER, de Boer BA, Geus JW (1999) The reduction and oxidation behaviour of manganese oxides. Catal Today 47:161-167

24. Tang X, Chen J, Li Y, Li Y, Xu Y, Shen W (2006) Complete oxidation of formaldehyde over Ag/ $\mathrm{MnO}_{\mathrm{x}}-\mathrm{CeO}_{2}$ catalysts. Chem Eng Sci 118:119-125

25. D́Alessandro O, Thomas H, Sambeth JE (2012) An analysis of the first steps of phenol adsorptionoxidation over coprecipitated Mn-Ce catalysts: a DRIFTS study. Reac Kinet Mech Cat 107:295-309

26. Hu B, Chen Ch, Frueh S, Jin L, Joesten R, Suib S (2010) Removal of Aqueous phenol and oxidation with doped hydrophobic cryptomelane-type manganese oxide (K-OMS-2) nanofibers. J Phys Chem C 114:9835-9844

27. Li Y, Du Q, Liu T, Sun J, Liao Y, Xia Y, Xia L, Wang Z, Zhang W, Wang K, Zhu H, Wu D (2012) Equilibrium, kinetic and thermodynamic studies on the adsorption of phenol onto graphene. Mater Res Bull 47:1898-1904

28. Mathew Th, Vijayaraj M, Pai Sh, Tope B, Hegde S, Rao B, Gopinath Ch (2004) A mechanism approach to phenol methylation on $\mathrm{Cu}_{1-\mathrm{x}} \mathrm{CoxFe}_{2} \mathrm{O}_{4}$ : FTIR study. J Catal 227:175-185 